NBER WORKING PAPER SERIES

\title{
FINANCIAL CRISES AND REFORM OF THE INTERNATIONAL FINANCIAL SYSTEM
}

\author{
Stanley Fischer \\ Working Paper 9297 \\ http://www.nber.org/papers/w9297 \\ NATIONAL BUREAU OF ECONOMIC RESEARCH \\ 1050 Massachusetts Avenue \\ Cambridge, MA 02138 \\ October 2002
}

This is a slightly revised version of the Harms Lecture delivered at the Kiel Institute of World Economics, June 29, 2002. I draw freely on Chapter 2 of my Robbins Lectures presented at the London School of Economics, October 29-31 2001, The International Financial System: Crises and Reform. I am grateful to Prachi Mishra of Columbia University for assistance, and to my former colleagues at the International Monetary Fund for their direct assistance and for many discussions over the years that helped develop the views expressed in this lecture. The views expressed herein are those of the authors and not necessarily those of the National Bureau of Economic Research.

(C) 2002 by Stanley Fischer. All rights reserved. Short sections of text, not to exceed two paragraphs, may be quoted without explicit permission provided that full credit, including (C) notice, is given to the source. 
Financial Crises and Reform of the International Financial System

Stanley Fischer

NBER Working Paper No. 9297

October 2002

JEL No. E5, E6, F3, F4, G1

$\underline{\text { ABSTRACT }}$

Between December 1994 and March 1999, Mexico, Thailand, Indonesia, Korea, Malaysia, Russia and Brazil experienced major financial crises which were associated with massive recessions and extreme movements of exchange rates. Similar crises have threatened Turkey and Argentina (2000 and 2001) and most recently Brazil (again). This article discusses the reform of the international financial system with a focus on the role of the IMF - reforms directed at crisis prevention, and those intended to improve the responses to crises. The article concludes with an appraisal of what has been achieved, and what remains to be done to make the international financial system safer.

\author{
Stanley Fischer \\ Citigroup \\ 399, Park Avenue \\ New York, NY 10022 \\ and NBER \\ fischers@citigroup.com
}




\section{Introduction}

The topic of the reform of the international financial system, or of the international financial architecture, rose to prominence in the wake of the financial crisis in Mexico in 1994-95. Interest in it intensified as a result of the Asian financial crisis in 1997-98, and deepened following the Russian and Brazilian crises in 1998 and 1999. The present debate is more narrow than that on the reform of the international monetary system in the decades of the nineteen sixties and seventies. Then the issue was how to replace the Bretton Woods system of fixed but adjustable exchange rates among the major currencies, and the role within the system of the International Monetary Fund.

Now the challenge is to reduce the frequency of crises among the emerging market countries, the mostly middle income developing countries that are open to international capital flows. In the last two years, Turkey, Argentina and most recently Brazil (again) have joined the list of emerging market countries that have experienced major external crises.

In considering the reform of the international financial system, I will first discuss reforms directed at crisis prevention, and then those intended to improve the responses to crises. I will conclude by discussing what has been done to make capital account crises less likely in future, and the priorities for action. 


\section{Crisis Prevention}

To reduce the probability of crises, changes are necessary in: first, country policies and institutions; second, the actions of the IMF and other official international financial institutions; and third, the operation of the international capital markets.

\section{Country policies and institutions}

Most crisis-prevention measures require improvements in a broad range of policies and the strengthening of institutions by countries seeking to participate in the international capital markets. I will focus on four issues: the choice of exchange rate system; fiscal policy; capital account liberalization; and the adoption of codes and standards.

Exchange rate systems: Except for Ecuador in 1998-99 and Brazil at present, every emerging market country that suffered a capital account crisis in the last decade had some form of pegged exchange rate in place before the crisis. The pegs were formal in the cases of Mexico, Brazil, Russia, Turkey, and Argentina, and each was initially part of a policy package to reduce inflation. The pegs were informal in the three Asian countries, and were not the remnant of an inflation stabilization program.

These crises reinforced the conclusion that the impossible trinity makes a softly pegged exchange rate non-viable when the capital account is open. ${ }^{1}$ The normal statement of the impossible trinity is that an open capital account, a pegged exchange rate, and an independent monetary policy are not consistent. If the peg is hard, such as a currency board, then monetary policy is automatically dedicated to maintenance of the peg. But as we have seen recently in Argentina, even a currency board peg is not

\footnotetext{
${ }^{1}$ See Fischer (2001a).
} 
necessarily viable, for if fiscal policy goes off track, and/or the financial system is weak, monetary policy alone may well not be sufficient to hold the exchange rate.

A country may succeed for some time in living with the impossible trinity, particularly if the exchange rate is undervalued. But when the capital account is open, a pegged exchange rate is crisis prone, vulnerable to a speculative attack, possibly producing a second generation crisis, in which the measures necessary to defend the peg are not politically viable.

In saying that a pegged exchange rate system is crisis prone, I am not claiming that the only viable system is one in which the exchange rate floats freely. Official interventions in the foreign exchange market from time to time can be useful, so long as they are not perceived as trying to defend a particular rate or narrow range of rates.

Following a float, a country has to decide what nominal anchor to adopt, and what exchange rate policy to pursue. For a country with a reasonable rate of inflation - one in the low double digits - experience increasingly supports the use of inflation targeting as the basis for monetary policy. Such a regime has been successfully introduced in Brazil, Korea, South Africa and several other emerging market countries - not all of them recent crisis countries.

Turning to exchange rate behavior: Most of the countries forced to float have been very unhappy about the subsequent behavior of the exchange rate, and have sought a middle way that provides more predictability for the exchange rate. It is hard not to sympathize with this desire, both because exchange rates moved far more after the crises 
than had been expected, and because there are good reasons for a country to be concerned about the behavior of both nominal and real exchange rates. ${ }^{2}$

Thus monetary policy in countries with floating exchange rate systems is likely to respond to movements of the exchange rate. While this is rarely if ever the case for the United States, it is more so among other G-7 countries, and for smaller emerging market economies. In Canada, the use in the past of a monetary conditions index to guide monetary policy, based on movements in both the exchange rate and the interest rate, formalized the impact of exchange rate movements on monetary policy. ${ }^{3}$ In countries that pursue an inflation targeting approach to monetary policy, changes in the exchange rate will be taken into account in setting monetary policy, because the exchange rate affects price behavior.

In the reverse direction, there is an unresolved issue about whether monetary policy in a flexible rate system should be used in the short run to try to affect the exchange rate. In many respects, the issue is similar to that of how monetary policy in an inflation-targeting framework should respond to movements in output and unemployment. Although it has not received much empirical attention, there is almost certainly a short-run tradeoff between the real exchange rate and inflation, analogous to the Phillips curve. ${ }^{4}$ This is an issue that deserves serious attention, for just as answers have been developed as to how to deal with the short-run Phillips curve in an inflation-

\footnotetext{
${ }^{2}$ Changes in the nominal exchange rate are likely to affect the inflation rate, and - especially in countries that are to some extent dollarized - also the health of the financial system and the distribution of wealth between debtors and creditors. Changes in the real exchange rate affect the current account of the balance of payments, often generating political pressures as a result.

${ }^{3}$ Although the idea behind the monetary conditions index (MCI), that both the exchange rate and the interest rate affect aggregate demand, is correct, the MCI needs to be used with great caution, not least because the cause of any change in the exchange rate needs to be taken into account.

${ }^{4}$ The paper by Cushman and Zha (1997) contains VARs from which the implied tradeoff can be calculated in the Canadian case.
} 
targeting framework, so it remains necessary to answer the question of how in such a framework to deal with the short-run tradeoff between the real exchange rate and inflation.

Recognizing the difficulty for an emerging market country of defending a narrow range of exchange rates, Williamson (2000) proposes alternative regimes. Rudi Dornbusch has named these BBC arrangements: basket, band, and crawl. Williamson also recommends that countries if necessary allow the exchange rate to move temporarily outside the band, so that they do not provide speculators with one-way bets that lead to excessive reserve losses. In these circumstances, the band is serving as a weak nominal anchor for the exchange rate, and can perhaps be thought of as a supplement to an inflation targeting framework. ${ }^{5}$ Goldstein (2002) argues that the best regime choice for emerging economies would be managed floating plus, where "plus" is shorthand for a framework that includes inflation targeting and aggressive measures to discourage currency mismatching ${ }^{6}$.

Although it is not clear that this type of intermediate regime will work for all emerging market countries, it is clear that floating exchange rates do fluctuate a great deal, and that it would be useful if it were possible to reduce the range of fluctuations. Some of the Asian crisis countries have been intervening regularly and apparently successfully in seeking to limit exchange rate fluctuations.

\footnotetext{
${ }^{5}$ Williamson himself believes that specifying a target exchange rate range may prevent markets heading off on an errant exchange rate path. Another possibility is that by committing weakly to some range of exchange rates, the authorities make it more likely that fiscal policy will be brought into play if the real exchange rate moves too far from equilibrium.

${ }^{6}$ Goldstein (2002) argues that if managed floating were enhanced in this way, it would retain the desirable features of a flexible rate regime while addressing the nominal anchor and balance-sheet problems that have historically underpinned a "fear of floating" and handicapped the performance of managed floating in emerging economies.
} 
Outside the transition economies, countries have not succeeded in stabilizing from high (triple digit) inflation without the use of an exchange rate anchor. But doing so, without an exit mechanism, is very risky. And it is risky even if an exit mechanism is specified, as the case of Turkey in 2000-01 shows. So I conclude that while an exchange rate peg could be used in future to help disinflate, the commitment would have to be quite short-lived if it were not to result in a pegged exchange rate-type crisis.

I believe that of all the changes in the international financial system that have taken place since 1994, the shift towards flexible exchange rates by emerging market countries is the one that has most reduced the risk of future crises. However, while a flexible exchange rate regime precludes some types of crises, external financing crises can still occur in a flexible exchange rate regime, particularly a crisis that arises from the market's conclusion that a country's debt situation is not sustainable - as we see in the case of Brazil at present. Accordingly we turn next to fiscal policy.

Fiscal policy: The IMF's emphasis on the key role of fiscal policy in the macroeconomic policy mix is well-known to the point of caricature. ${ }^{7}$ The discussion usually turns on the need for fiscal contraction in the face of a variety of adverse external shocks. But sometimes, the IMF has recommended fiscal expansions, for instance in Japan in recent years, and after a short while, during the Asian crisis.

How should the required fiscal policy be calculated? In several programs, for instance those in Brazil, Argentina, and Turkey in the period since 1998, the agreed fiscal stance has been guided by the need to ensure that the debt to GDP ratio is put on a declining path. The well-known equation for debt dynamics is

\footnotetext{
${ }^{7}$ The focus here is on the macroeconomic aspects of fiscal policy.
} 


$$
\dot{d}=-x+(r-g) d
$$

where $d$ is the debt-to-GDP ratio, $x$ is the primary surplus (relative to GDP), $r$ is the interest rate, and $g$ the growth rate of GDP.

If a country is in an external funding crisis because the markets are concerned that the debt burden is non-sustainable, then the fiscal policy will have to be such as to persuade investors - domestic and foreign - that the debt-to-GDP ratio will at some point begin to decline. In a crisis, it is likely the real interest rate will be high and the growth rate will be low, tending to make for unsustainable debt dynamics - but also reinforcing the likelihood that if a credible change can be made in fiscal policy, then an apparently unstable debt dynamics will become stable. ${ }^{8}$

But theory has not provided a great deal of guidance about an optimal debt to GDP ratio. The issue was discussed in the United States during the period, not so long ago, when it was believed the government debt was about to disappear. The Maastricht upper limit of 60 percent of GDP seems to have gradually gained status as a norm. Whatever theory ultimately emerges, it is likely that if an optimal government debt to GDP ratio can be defined, it would be related to the private sector's saving behavior. It would also be related to the terms on which the government can borrow, and the variability of those terms, as well as the average rate of growth and its variability.

Interest rates paid by emerging market governments are not only higher but also vary a great deal more than those paid by industrialized country governments. For instance, over the period 1995 to 2000 , during which the real interest rate paid by the United States and United Kingdom governments had a standard deviation of 0.86 percent

\footnotetext{
${ }^{8}$ This point is developed in Favero and Giavazzi (2002).
} 
per annum, the standard deviation for Korea was more than double that, and that for Mexico and Brazil - which averaged 4.2 percent per annum ${ }^{9}$ - greater by a factor of five. This means that at any given debt-to-GDP ratio, the budget of an emerging market country is more vulnerable to interest rate shocks than the budget of an industrialized country. Further, the costs of borrowing are likely to be highly non-linear as a function of the debt-to-GDP ratio. We have also seen in recent years, in both Russia and Argentina, just how quickly a debt ratio can rise if the budget deficit is large and growth is slow or negative.

The conclusion is that if there is an optimal debt-to-GDP ratio, it must be smaller for an emerging market country than for an industrialized country - equivalently, that emerging market countries that become too dependent on the international capital markets, court great danger. Even if it is not possible to define an optimal debt-to-GDP ratio, it can safely be concluded that a 60 percent ratio for an emerging market country is too high, and that ratios nearer 30-40 percent are much safer.

Capital controls: The debate over capital controls has taken on an ideological cast that seems to have intensified during the most recent discussions. In principle capital controls can enable a country to have the benefits of both a pegged exchange rate and an independent monetary policy, and also to control both capital outflows (and thus the extent of private sector borrowing) and inflows. ${ }^{10}$

\footnotetext{
${ }^{9}$ The underlying data for standard deviations of real interest rates (quarterly data) are 0.88 for the US, 0.92 for the UK, 1.88 for Korea, 3.66 for Mexico, and 4.71 for Brazil.

${ }^{10}$ Capital controls are examined by De Gregorio et al(2000), Eichengreen et al (1999) and Williamson (2000); for more detailed discussion of experience with capital controls, see Ariyoshi et al (2000).
} 
As is well known, the founders of the Bretton Woods system, reflecting the prevailing interpretation of inter-war experience, ${ }^{11}$ regarded short-term capital flows as being frequently destabilizing. The Articles of Agreement of the IMF do not make capital account liberalization a purpose of the Fund, and Article VI permits the Fund to ask a member to exercise capital controls to prevent the general resources of the Fund being used "to meet a large or sustained outflow of capital".

Most industrialized countries kept capital controls in place for most of the postWorld War II period; even in the United Kingdom the last capital account restrictions were removed only in the late 1970s. China and India, both countries with capital controls, successfully avoided the Asian crisis, thereby providing an important element of stability in the regional and global economies at the time. Malaysia's imposition of capital controls and pegging of the exchange rate in September 1998 has attracted much attention, though evaluation of the effects of the controls has been difficult, since they were imposed after most of the turbulence of the first part of the Asian crisis was over, that is after most of the capital that wanted to leave had done so, and when regional currency values were close to their post-crisis minima. ${ }^{12}$

Nonetheless, support for capital controls is often seen as inconsistent with the Washington Consensus, ${ }^{13}$ and a belief in free markets. In discussing capital controls, I shall assume that countries will in the course of their development want to liberalize the capital account and integrate into global capital markets. This view is based in part on the fact that the most advanced economies all have open capital accounts; it is also based

\footnotetext{
${ }^{11}$ League of Nations, International Currency Experience, 1944, reprinted by Arno Press, 1978. Most of the volume was written by Ragnar Nurkse, to whom it is sometimes attributed.

12 See Kaplan and Rodrik (2001) for a relatively positive appraisal of the Malaysian controls.

13 The original Washington Consensus list (Williamson, 1990) did not include capital account liberalization, except for foreign direct investment.
} 
on the conclusion that the potential benefits of well-phased integration into the global capital markets - and this includes the benefits obtained by allowing foreign competition in the financial sector - on balance outweigh the costs. ${ }^{14}$

It is necessary to distinguish between controls on outflows and controls on inflows. For controls on capital outflows to succeed, they need to be quite extensive. As a country develops, these controls are likely to become both more distorting and less effective. They also cannot prevent a devaluation if domestic policies are fundamentally inconsistent with maintenance of the exchange rate.

If a country intends to liberalize capital controls on outflows, they could be removed gradually, at a time when the exchange rate is not under pressure, ${ }^{15}$ and as the necessary infrastructure - in the form of strong and efficient domestic financial institutions and markets, a market-based monetary policy, an effective foreign exchange market, and the information base necessary for the markets to operate efficiently - is put in place. Unless the country intends to move to a hard peg, it could be desirable to begin allowing some flexibility of exchange rates as the controls are gradually eased. Prudential controls that in practice have a similar effect to some capital controls, for instance limits on the open foreign exchange positions that domestic institutions can take, could also be put in place as direct controls are removed.

\footnotetext{
${ }^{14}$ The argument is developed at greater length in Fischer (1998). The point has been much disputed, including by Bhagwati (1998). With regard to empirical evidence on the benefits of capital account liberalization, I believe we are roughly now where we were in the 1980s on current account liberalization that some evidence in favor of the proposition is coming in , but that it remains highly disputed. Reinhart and Tokatlidis (2002), Chari and Henry (2002), Bekaert et al (2002), Gallindo et al (2002), Gourinchas and Jeane (2002) provide empirical evidence and discuss whether financial liberalization spurs growth and through what channels.

${ }^{15}$ The removal of controls on outflows sometimes results in a capital inflow, a result of either foreigners and/or domestic residents bringing capital into the country in light of the greater assurance it can be removed when desired.
} 
Some countries have attempted to impose controls on outflows once a foreign exchange crisis is already under way. This use of controls has generally been ineffective. ${ }^{16}$ It has also to be considered that the imposition of controls for this purpose in a crisis is likely to have a longer-term effect on the country's access to international capital.

Several countries, among them Singapore, the three Asian crisis countries, and Malaysia have taken steps to limit the offshore use of their currencies. In principle this makes it possible to break the link between onshore and offshore interest rates, particularly by restricting the convertibility of the currency for nonresidents - who need access to the domestic banking system to complete their transactions. ${ }^{17}$ Ishii et al (2001) conclude that such restrictions have been more successful the more comprehensive they have been, and that they could provide the authorities with a breathing space in which to implement policy changes. But as with other capital controls, their effectiveness tends to erode over time. Further, the longer the measures are implemented, and the stronger they are, the higher the associated costs in terms of the efficiency of the financial system are likely to be.

Excessive international indebtedness of domestic financial and non-financial institutions arises not from capital outflows, but from inflows, especially short-term inflows. The IMF has cautiously supported the use of market-based capital inflow controls, Chilean style. These could be helpful for a country seeking to avoid the difficulties posed for domestic policy by capital inflows. The typical instance occurs when a country is trying to reduce inflation using an exchange rate anchor, and for anti-

\footnotetext{
${ }^{16}$ See Ariyoshi et al (2000), pp 18-29, and Edwards (1999), pp 68-71.

${ }^{17}$ See Ishii et al (2001). This paper describes three different mechanisms that are used to limit offshore currency trading.
} 
inflationary purposes needs interest rates higher than those implied by the sum of the foreign interest rate and the expected rate of currency depreciation. A tax on capital inflows can help maintain a wedge between the two interest rates. In addition, by taxing short-term capital inflows more than longer-term inflows, capital inflow controls can also in principle influence the composition of inflows.

Evidence from the Chilean experience implies that controls were for some time successful in allowing some monetary policy independence, and also in shifting the composition of capital inflows towards the long end. Empirical evidence presented by De Gregorio et al (2000) suggests that the Chilean controls lost their effectiveness after 1998. They have recently been removed.

Thus, controls can be used to help limit capital outflows and maintain a pegged exchange rate, given domestic policies consistent with maintenance of the exchange rate. However such controls tend to lose their effectiveness and efficiency over time. Capital inflow controls may for a time be useful in enabling a country to run an independent monetary policy when the exchange rate is softly pegged, and may influence the composition of capital inflows, but their long-term effectiveness to those ends is doubtful. In a nutshell: capital controls may be useful provided they are exercised with care; they are likely to be transitional - albeit possibly in use for a long time - and caution is likely to be necessary in removing them.

A capital account amendment to the articles of agreement of the IMF was on the agenda at the annual meetings of the IMF in Hong Kong in $1997 .^{18}$ Given recent controversies about capital flows, it is no longer on the agenda. But it could be restored

\footnotetext{
${ }^{18}$ The Interim Committee agreed in April 1997 that there would be benefits to amending the Articles of Agreement to make capital account liberalization a purpose of the Fund, and to extend the Fund's jurisdiction to capital movements.
} 
to the agenda: the Fund could be given the orderly liberalization of the capital account as one of its purposes. Just as is the case with current account liberalization, countries could elect to maintain capital account restrictions (the equivalent of Article XIV of the articles), and, when ready and willing, could accept the obligations of an open capital account (the equivalent of Article VIII).

What benefits might this bring? For countries, it would provide a framework in which to think about their present capital controls, possibly to rationalize them, and eventually to undertake capital account liberalization. For the Fund, it would put centerstage a set of issues that is critical to the operation of the international capital markets and the frequency of crises. And for the Fund and the economics profession, it would provide more incentives to develop a body of knowledge about capital account restrictions and how best to remove them. It is striking that while accepted principles exist for current account liberalization - for instance, first replace quantitative restrictions by tariffs, then gradually reduce tariffs and their dispersion - we have few established principles about the removal of capital account restrictions. It is generally accepted that if the capital account is to be liberalized, that should be done at the long end first, that there should be few restrictions on foreign direct investment, and that Chilean-style inflow controls can be useful, these views do not cover all capital account issues, and in any case need further substantiation and refinement.

The adoption of codes and standards: In considering systemic reforms after the Mexican crisis, the initial reaction was to emphasize the need to provide better information to the markets. The Special Data Dissemination Standard (SDDS), introduced in 1996, was developed in response. It describes a set of data, and information on procedures for their 
release, that subscribing countries have to meet. At present 50 countries have subscribed, including most emerging market countries. The General Data Dissemination System (GDDS) was developed subsequently for countries that do not yet aspire to meet the SDDS; the GDDS sets out procedures by which participating countries can gradually improve the quality of their data, with the assistance of the IMF.

Probably the most important improvement made under the SDDS is to bring uniformity to the release of information on reserves. The reserves template requires countries to make data on reserves available at least monthly, with no more than a onemonth lag. ${ }^{19} 20$ Data on forward commitments have to be revealed. The requirement to provide external debt data is also extremely important - one of the main tasks the IMF found itself undertaking in its meetings with the private sector immediately following the outbreak of a crisis was trying to reconcile different external debt estimates.

If Thailand and Korea had been meeting the conditions on the release of reserve data before their crises, the markets would have known about the declining reserves much sooner, and Thailand would have been forced to reveal its forward interventions in the foreign exchange market. Each country would almost certainly have had to allow the exchange rate to move earlier, well before exhausting their reserves. ${ }^{21}$ It is also possible

\footnotetext{
${ }^{19}$ The IMF staff would have preferred weekly data, but some leading central banks objected. They argued that unless private sector participants were required to provide information on their positions, the central banks would be at a disadvantage if required to provide frequent and up-to-date information on their reserves.

${ }^{20}$ Many countries do better than this, including Turkey whose reserves data are available daily, and were for a while available in real time.

${ }^{21}$ The Mexican case is more complicated, since their reserves declined in two steps, first following the Colosio assassination in April 1994, and then in November. It is thus not obvious that adherence to the present reserve template would have produced an earlier exchange rate adjustment.
} 
that if this information had been generally available, the political system in each country would have forced a policy adjustment on the central bank sooner. ${ }^{22}$

As this discussion suggests, transparency is important not only because it provides more information to the markets, but even more because it puts constraints on what policymakers can do. Subsequently the IMF developed Codes of Good Practices on Transparency in Monetary and Financial Policies, and on Fiscal Transparency, respectively. These set out standards against which countries can measure their own practices, and where necessary, seek to improve them. The Fund helps countries appraise their practices.

Countries' performance in meeting four standards in other areas - the Basel Committee's Core Principles for Effective Banking Supervision, and standards for securities regulation, insurance supervision, and payments systems - are assessed as part of the FSAP, the Financial Sector Assessment Program, a joint effort of the IMF, the World Bank, and national supervisory agencies. The World Bank is taking the lead in assessing standards in four other areas: corporate governance (standard developed by the OECD); accounting (IASC); auditing (International Federation of Accountants), and insolvency and creditor rights (principles developed by the World Bank).

Each standard provides a yardstick by which a country can appraise its performance in the relevant area, and seek to meet international standards. The key questions then are what are the incentives and obstacles to meeting the standards. The answers depend in part on how these systems are appraised, how and to whom the information is made public, what assistance is provided to help countries upgrade their

\footnotetext{
${ }^{22}$ The report of the Nukul Commission on the Thai crisis (The Nation, Bangkok, March 31, 1998) states that information on reserves was very tightly held within the Bank of Thailand.
} 
performance, and how investors take country performance in these areas into account in making their investment decisions. Among the incentives should be the desire of policymakers to strengthen the economy and reduce the probability of crisis - an incentive that should always be present. Each country's performance in meeting a specific standard is monitored by the relevant body, and the results are summarized in a ROSC - report on the observance of standards and codes - that is posted on the internet. $^{23}$

Nothing would help improve standards more than if countries that met higher standards were rewarded with lower borrowing costs. ${ }^{24}$ It is early yet to tell whether spreads are lower for countries that meet relevant standards. However, anecdotal evidence and discussions with some market participants suggest that awareness of the contents of ROSCs is growing. If this awareness translates into lower spreads, the standards initiative will begin to pay off not only for individual countries, but also for the system as a whole.

\section{Actions by the Fund}

Much of what the IMF could do to prevent crises - the work on standards and codes, and the possibility of a capital account amendment to the Articles of Agreement has already been discussed. In addition, the FSAP is an extremely important initiative, which is helping member countries strengthen their financial systems. I shall focus on

\footnotetext{
${ }^{23}$ By the end of September 2001, 169 ROSC modules had been completed for 57 countries.

24 One such incentive should have been provided by the fact that to qualify for the Contingent Credit Line (CCL) facility, a country has to be making satisfactory progress towards meeting international standards, particularly the SDDS, the Basle Committee's Core Principles for Banking Supervision, and the Codes on Fiscal Transparency, and on Transparency in Monetary and Financial Policies, respectively. However, the CCL has had no takers.
} 
three areas: improving surveillance, increasing transparency, and the possibility of prequalification for loans.

Improving surveillance: The Mexican crisis took the IMF by surprise, and it was easy to conclude that better surveillance would have helped prevent the crisis - particularly because at that time the IMF did not make much effort to monitor market and economic developments in real time. It was only after the Mexican crisis that news and financial data screens were widely installed in the Fund.

It is hard to quarrel with the notion that improved surveillance should help reduce the frequency of crises, and that Fund surveillance through the annual Article IV report, along with more frequent interim interactions with member countries, should contribute to this end. ${ }^{25}$ Fund surveillance has improved greatly since $1994 .^{26}$ The private dialog between the management and staff of the IMF and the officials of a country can be very frank indeed. Reporting to the Board is also typically very frank. ${ }^{27}$

A key question is whether the Fund should issue public warnings - a system of yellow and red cards - when it believes a country is heading for a crisis. In issuing warnings of potential trouble, whether in private or in public, the IMF has to be mindful of two types of error: the type 1 error of crises that were not predicted; and the type 2 error of a crisis that was predicted but did not happen. It has particularly to be concerned that its warnings may be self-justifying - and this is a difficult problem to deal with, one

\footnotetext{
${ }^{25}$ Given the quantity of private sector research on industrialized and emerging market countries, the question arises whether the Fund has any advantage in undertaking surveillance of these countries. Part of the answer should be the quality of the Fund staff; in addition, Fund staff and management are likely to have a closer dialog with country officials, and may well have access to better information about policies and policy intentions.

${ }^{26}$ In 1999, a group of experts headed by John Crow, former Governor of the Bank of Canada, presented a report on Fund surveillance. See External Evaluation of IMF Surveillance: Report by a Group of Independent Experts, IMF, September 1999.

${ }^{27}$ I discuss below how such concerns are reflected in published reports.
} 
that member countries tend to emphasize. Members of the IMF Executive Board often repeat that they do not want the Fund to become a rating agency. ${ }^{28}$

The Fund has rarely issued a clear public warning of an impending crisis, but does express concerns that make the point. How would it have done if it had issued public warnings? Of the six major crises between 1994 and 1999, three were on the Fund's radar screen well before they happened - Thailand, Russia, and Brazil - and three were not, despite concerns having been expressed about some weaknesses in each of the Mexican, Indonesian, and Korean economies. During the crisis period, I predicted, within official circles, at least one crisis that didn't happen. Type 2 errors of this sort are especially worrisome. $^{29}$

In addition to self-justifying predictions, it is necessary to consider warnings that may be self-negating - warnings of a potential crisis that induce a country to take action that averts the crisis. I have seen policy actions taken in some economies that in my view prevented crises. In such cases, success has many parents, and since it is the authorities within the country who have responsibility for policy decisions, they rightly tend to take the credit for averting the crisis. ${ }^{30}$

While I can envisage circumstances in which the Fund should issue public warnings - and in essence it did that a few weeks before the Thai devaluation - the quiet approach is more likely to be the norm. Public warnings are especially difficult when a country is in an IMF program. If the Fund sees a problem coming, it warns the country,

\footnotetext{
${ }^{28}$ The Fund publishes each quarter a list of the about 40 countries whose currencies are usable for Fund lending; since the criterion for being on the list is to have a strong balance of payments and reserve position, this is a rating, albeit it a not very refined one.

${ }^{29}$ If Fund warnings were self-justifying, there would not be any type 2 errors.

${ }^{30}$ I once took an informal poll inside the IMF asking for examples of crises averted; there were more than I expected, even after adjusting for multiple parentage. I am not aware of more scientific results on this issue.
} 
increasingly urgently, that the program is in danger. If the country does not respond, the Fund can cut off financing, or issue a public warning. But in these circumstances, the public warning is especially likely to be self-justifying. This dilemma is very real, and has arisen several times in recent years.

Why do countries fail to take action when warned? For one thing, as the late Herb Stein used to say, economists are very good at predicting that something cannot go on forever, but are less good at saying when it will end. (Stein's corollary is that if something cannot go on forever, it will end.) When warning a finance minister about the non-sustainability of the current situation, I was sometimes told that I or someone else said the same thing a year or more ago, and we were wrong. The response is to tell the story of the person on the way down after jumping out of a fortieth floor window, but that usually does not work - for it is rarely the case that those being warned are unaware of the dangers they run; rather there are usually reasons, good or bad (often political), for what they are doing. For another thing, policymakers embarked on a dangerous policy path tend to argue that there is something special about their economy that makes it immune to the normal rules of economics. Sometimes the officials concerned may believe that the trouble will come later, on someone else's watch. And sometimes they are right to ignore a warning, for it is wrong - but much less frequently than asserted by those being warned.

It has sometimes been suggested that the Fund should refuse to lend to countries that get into a crisis after ignoring warnings. The idea of providing incentives to heed warnings is attractive, but this punishment may be too draconian. For not only are some warnings wrong, but also, in refusing to help a country that is willing to implement the 
mandated policies, the IMF would be punishing the entire population because of the actions of a few policymakers who failed to respond to warnings - and who have probably been fired in the meantime. There is however a case for developing a procedure in which the terms of lending are adjusted depending on the country's previous behavior - though there is a delicate balance to be struck between providing incentives to heed warnings and providing disincentives to come to the Fund when trouble looms.

Beyond the standard traditional human intelligence aspects of surveillance, the Fund has invested in the statistical analysis of vulnerability indicators, as predictors of the probability of a crisis. ${ }^{31}$ Similar exercises are undertaken in the private sector, and are published. While these efforts are interesting and the results worth close scrutiny, their forecasting record is not very good; further, to the extent that any one of these equations fits well and is used successfully to avert some crises, it may carry the seeds of its own destruction, in Goodhart's law or Lucas critique fashion. ${ }^{32}$

The Fund is strengthening the vulnerability analyses it carries out for internal purposes: these bring together the statistical analyses with detailed country-by-country reports in seeking to identify countries that are vulnerable, and to recommend appropriate policy measures. While it should continue to strive to make surveillance ever better, we need also to keep reminding ourselves that no early warning system will be infallible.

Transparency: At the time of the Mexican crisis, the IMF published very little about its programs, its policy deliberations, and its surveillance activities - except for the World Economic Outlook and the International Capital Markets Report. If the Board agreed to

\footnotetext{
${ }^{31}$ See IMF(2000) and Goldstein et al (2000).

${ }^{32}$ Berg et al (2000)
} 
support a program, an announcement of the amounts involved would be made. Program documents were not published. Nor were Article IV reports.

Now the great majority of IMF members publish their Article IV conclusions (in the PINs - Public Information Notices) and more important, most agree to the publication of the Article IV reports themselves. ${ }^{33}$ Most borrowers release the Letters of Intent that describe their IMF-supported programs. In addition, since the start of 2001, countries have been allowed to publish the staff reports on programs, and about half have been published since then. Staff papers on general policy issues are almost all published, sometimes also in preliminary form to solicit public comment. In addition, an Independent Evaluation Office, reporting to the Board, has been established and is beginning to operate.

All this marks a revolution in transparency, and a revolution within the Fund. At the time the changes were being debated within the Fund, some Board members feared that greater transparency would inhibit the frankness of the policy dialog between the Fund and its members, and the frankness of reporting to the Board. The objection was a serious one, even if it sometimes came from members with whom the policy dialog was not particularly frank. It was dealt with in part by allowing members to request the removal of market-sensitive information from reports that were later to be published. ${ }^{34}$ On balance I do not believe the fears have turned out to be valid, though from time to time in clearing a report, I was mindful of the fact that the report would be made public.

\footnotetext{
${ }^{33}$ Publication rates of Article IV's are highest for the advanced, Central and Eastern Europe, and Western Hemisphere members.

${ }^{34}$ All changes made between Board presentation and publication of a report have to be reported in complete detail to the Board - this serves as a safeguard against changes that do not meet the marketsensitivity test.
} 
The main argument for transparency put forward a few years ago was that it helps make markets more efficient. That it does, despite the difficulties skeptical markets frequently create for member countries and for the Fund. But transparency has many other benefits. As already mentioned, it improves policy, because policymakers operating in the light of day cannot do some of the things they can do in the dark of secrecy. It also improves the quality of the Fund's work, for Fund staff and management are bound to be even more careful to get it right when subject to scrutiny - and here the Independent Evaluation Office will also make an important difference.

But transparency does even more than that, in two regards. First, it promotes interactions with the outside world, for as the Fund puts information out, it has also to interact with the outside, listening to what outsiders are saying, and taking information in. This happens in a variety of ways: the posting of papers for comment on the web; the setting up of the Capital Markets Consultative Group, a group of private sector capital market participants with whom general issues - but not the details of individual country cases - are discussed; and increased interactions with NGOs in both the industrialized and developing countries. In addition, transparency improves the depth and the quality of the interactions with the academic community. The Fund has to be careful in all these interactions not to betray the trust of its members by revealing privileged information, or by giving anyone favored access - and doing so requires real skill and tact.

Second, transparency strengthens the potential effectiveness of Fund surveillance over non-borrowing countries. In that regard, consider the United States. The US government used to ignore the annual Article IV report, and hardly anyone outside official circles got to see it. The Article IV report for the United States for 2001 was 
certainly not ignored: it was the subject of many news reports and of several op-ed columns in leading newspapers. And all the attention it received ensures the next ArticleIV consultation with the U.S. will be treated more seriously by the United States authorities than in the past. Of course there is also a risk - namely that Fund surveillance fails to establish a track record. Which is to say, transparency strengthens the incentives for the Fund to do top-class work.

Let me confess also to a third argument that was sometimes on my mind - that transparency probably contributes a bit to democracy.

Looking back, I regard the transparency revolution as the most important change in the IMF during the seven years I was there. This is not simply a bureaucratic change; it is a culture change. It has some costs - but it is overwhelmingly a positive development.

Prequalification for loans: The Meltzer Commission recommended that the Fund move over five years towards a system in which countries would have to prequalify for loans, particularly by meeting strong standards for the health of the banking system. ${ }^{35}$ Loans would be disbursed automatically if triggered. Other countries would not receive loans, except in cases of systemic risk.

Relying solely on prequalification for loans would set up the right incentives to meet the qualification conditions. However, automatic disbursement, independent of the country's macroeconomic policies, would not make sense, even if the country's overall policies had been good at the time the line of credit was negotiated, for macroeconomic conditions are almost bound to have changed at the time the country needs to draw on its

\footnotetext{
35 The report of the Meltzer Commission (the International Financial Institution Advisory Committee) is available at $<$ http://www.house.gov/jec/imf/ifiac.htm $>$.
} 
line of credit. Further, while incentives for prequalification make sense, the Fund might well find difficulty in not lending to non-prequalifying crisis countries that have demonstrated post-crisis their willingness to adjust their policies to deal with the crisis. The discussion here parallels that about the suggestion that the Fund not lend to countries that ignore warnings provided by the Fund - and we should note also that the Meltzer Commission's systemic risk contingency is one that discriminates against smaller countries.

Nonetheless, the notion of prequalifying for lending is an important one, which is embodied in the conditions for the CCL - Contingent Credit Line facility. The basic idea is straightforward: the IMF offers a precautionary line of credit to countries that have demonstrably sound policies, but which nonetheless believe they may be vulnerable to contagion from crises elsewhere. In effect, it allows countries that have met certain preconditions to augment - at low cost - the foreign exchange reserves they can draw on in a crisis. The knowledge that these resources are available may in itself deter a speculative attack. By offering qualifying countries a seal of approval for their policies, it should also reduce contagion, by giving less reason for investors and creditors to pull their money out because of crises elsewhere.

The adoption of the CCL marked an important departure from the Fund's traditional lending activities. Rather than waiting to pick up the pieces after an accident has happened, the intent behind the introduction of the CCL was to use the Fund's lending capacity for crisis prevention, as well as crisis resolution. This obviously creates a risk of moral hazard. Countries have an incentive - in theory at least - to run weaker policies if they have an extra financial cushion in place. Perhaps more importantly, 
investors have an incentive to lend to countries with weaker policies if they believe that the presence of the credit line increases the chances that they will be repaid if things go wrong.

To counter this problem, the CCL was aimed explicitly at members with firstclass policies, who would face a potential loss of access to international capital markets because of contagion rather than domestic policy weaknesses. But we do not live in a Manichaean world in which we can divide countries neatly between the righteous and the ungodly. So "first-class" should not be taken to mean "perfect". The eligibility criteria are demanding, but not so much so that they would disqualify any country that might benefit from signing up. ${ }^{36}$

To date, the CCL has not been adopted by any country, and as time goes by, it seems less likely that it will be adopted. In part this was because of a Groucho Marx-like concern that no country that was eligible would want to join the club. It is not clear whether a further reformulation of the facility would lead to its use, but as of now it seems that this important attempt to make the Fund's financial resources available for crisis prevention has failed.

\section{Actions by others}

Almost every suggestion for change identified so far relates to the behavior of the emerging market economies or the IMF. But the behavior of the suppliers of international capital in the industrialized countries, particularly the financial institutions, also contributes to the excessive volatility of international capital flows, and thus to

\footnotetext{
${ }^{36}$ The key conditions are (i) at the time the credit line is agreed, the country is not expected to need to borrow from the Fund; (ii) the country's economy is in good shape, and it is making progress towards meeting relevant international standards; and (iii) the country must enjoy constructive relations with its private creditors, and be taking appropriate steps to limit its external vulnerability.
} 
financial crises. This is the theme of Dobson and Hufbauer $(2001)^{37}$, who argue (p.129) that "Changing the rules of the game in industrial countries is at least as important as strengthening the regulators and financial institutions in the emerging markets." This view was shared by the authorities in some Asian countries, who attributed the crises to the behavior of hedge funds.

Dobson and Hufbauer trace many of the capital flow reversals during crises to the behavior of short-term flows, intermediated in some way by banks (including, for instance, providing credit to hedge funds), subject to moral hazard caused by explicit and implicit insurance in the host countries. Their proposed solution is a set of measures for strengthening the new Basel Capital Accord, improving financial system regulation in part through increasing the accountability of supervisors, tightening the frameworks governing G-10 deposit insurance, and undertaking a review of the behavior of large portfolio investors with the goal of designing "disclosure rules and other incentives that would forestall large portfolio swings from becoming a future financial problem" (p.165). They also recommend creating a clear ex-ante framework for private sector involvement in the resolution of international financial crises, a topic to which I will turn later.

The issue here is not the goals, which are admirable, but whether better rules and regulations can be designed. After all, the revised Basel Accord took a considerable amount of work and time, and will take several more years to go into effect. With regard to hedge funds, an IMF study found that a wide range of financial institutions, including banks, had engaged in the same behavior as the hedge funds. ${ }^{38}$ That conclusion could point two ways, but policymakers in the leading countries whose institutions supply

\footnotetext{
${ }^{37}$ Dobson and Hufbauer (2001).

${ }^{38}$ Eichengreen et al (1998).
} 
funds took the view that the type of systemic risk that emerged in the LTCM case could best be handled by greater diligence by the lenders to hedge funds. These conclusions left the authorities in some Asian and some European countries unconvinced, but a subsequent Financial Stability Forum study ${ }^{39}$ was not able to push towards any consensus on the need for or possibility of greater disclosure of position-taking by financial institutions participating in emerging markets. Although it is doubtful that a different consensus will emerge anytime soon, this issue should remain on the agenda.

Dobson and Hufbauer also call for better coordination among G-10 supervisors and regulators. The Financial Stability Forum was set up in 1999 to bring financial supervisors from the G-7 together with their finance ministry and central bank deputies, along with representatives of the major international regulatory agencies, and IFI officials. As a forum, the FSF has a very small bureaucracy, but is able to draw on the institutions associated with it, and others, to prepare reports on major financial issues and it has been active in this regard, producing several good reports. Its biannual meetings start with a surveillance discussion seeking to identify vulnerabilities in the international financial system, and in financial systems in individual countries. It is not clear yet to what extent the FSF has contributed to strengthening supervision in the international financial system.

The G-20 was also set up in the aftermath of the Asian crisis. Its membership is very similar to that of the IMFC - the International Monetary and Financial Committee the ministerial level body that in effect governs the IMF. Given competing demands on the time of officials, rationalization of the proliferation and overlap of institutions in the international system could be desirable.

\footnotetext{
${ }^{39}$ Financial Stability Forum, Report of the Working Group on Highly Leveraged Institutions, Basel, 2000.
} 


\section{Crisis Response and Private Sector Involvement (PSI)}

While it is convenient to draw a distinction between crisis prevention and crisis response, the line cannot be clearcut, for the way the Fund and the international system respond to crises also helps determine behavior before a crisis.

No issue in the debate over the reform of the system has generated more heat than that of PSI. The term is used in several senses. The literal meaning is the contribution of the private sector to meeting a country's financing needs. In the debate over how the IMF should ensure PSI, the term is often used to mean non-business-as-usual ways to persuade the private sector to reduce net capital outflows from a country facing a capital account crisis. Some mean by PSI the losses or pain borne by foreign private investors during a crisis.

These different conceptions of PSI are relevant to distinct but related concerns about IMF lending. The first recognizes that given the scale of capital flows to emerging market countries, the public sector is unlikely to be able fully to offset swings in private capital flows, and that the private sector one way (voluntarily) or another (involuntarily) needs to provide some of the needed financing. ${ }^{40}$ This leads to the second sense of PSI that the IMF may on occasion need to find ways of helping ensure the private sector provides some of the financing.

The third - pain - sense is relevant to the efficiency of the operation of the capital markets, and to moral hazard. If markets are to operate efficiently, investors need to bear

\footnotetext{
${ }^{40}$ The question of the optimal size of the IMF and of individual programs could be analyzed using a costbenefit analysis, in which at the margin the benefit to the global economy of an extra dollar provided to the IMF is equal to its marginal cost. There are of course formidable difficulties in quantifying the benefit to the global economy, including the need to weight the gains to different groups in the global system.
} 
the real risks associated with their investments, and IMF programs should not shield them from that. ${ }^{41}$ Otherwise moral hazard will lead investors to make decisions based on beliefs about extraordinary rescue packages rather than a careful appraisal of the real value of the investment. ${ }^{50}$ And if that happens, a successful rescue could contain the seeds of a future crisis.

Some emphasize fairness as much as efficiency, arguing that investors should not be bailed out by loans financed by advanced country taxpayers. In fact, IMF crisis loans have always been repaid ${ }^{42}$ - often early - and the industrialized country taxpayers do not bear a burden. ${ }^{43}$ Rather the loans are repaid by the taxpayers of the borrowing country and accordingly many argue that investors are being bailed out by imposing a burden on domestic residents. To clinch this argument, it would be necessary to spell out what the alternative course of action for the crisis country would have been. There would surely have been substantial costs associated with any other course of action, such as defaulting on the debt.

For all three reasons - particularly because it does not have and should not have enough money to do otherwise - the IMF has to be concerned with private sector involvement in the resolution of financial crises. However the issue has to be approached carefully, lest proposed solutions increase the frequency of crises. For instance, the formalization of a requirement that the banks, or any other set of creditors, always be forced to share in the financing of IMF programs, would be destabilizing for the

\footnotetext{
${ }^{41}$ A great deal lies behind this sentence: in particular, if optimal IMF operations can sustainably (in the stochastic equilibrium of the system) reduce the variability of output in emerging market economies, then the real risks facing investors are those in the equilibrium in which the IMF is acting optimally.

${ }^{42}$ A few countries (among them Sudan, Democratic Republic of the Congo, Liberia) are in arrears to the IMF, but these are not countries that suffered capital account crises - rather they suffered from conflict and civil wars.

${ }^{43} \mathrm{I}$ leave aside here the issue of whether the subsidy implicit in lending to crisis countries at IMF rates is a burden on the providers of funds.
} 
international system. If such a condition were insisted on, the creditors would have a greater incentive to rush for the exits at the mere hint of a crisis. This is a real dilemma, one that suggests the need for a differentiated approach to involving the private sector, one that depends on the circumstances of each country: sometimes a formal approach may be necessary, as in Korea at Christmas in 1997; at other times, as in the case of Brazil in March 1999, when the commercial banks voluntarily agreed to maintain their lines of credit, less formal discussions could serve better; when financing needs are small, there may not be a need to approach the creditors; and in extreme and infrequent cases, an involuntary restructuring of the debt may be necessary.

The IMF's approach to private sector involvement is in a state of flux, but the framework in which it operates in practice is probably still best described by an agreement reached among the membership at the annual meetings in Prague in September $2000 .^{44}$ The approach emphasizes the need to rely as much as possible on marketoriented and voluntary solutions.

The basic principles of the framework are that official financing is limited; that debtors and their creditors should take responsibility for their decisions to borrow and lend; and that contracts should be honored, except in extremis. The approach taken in individual cases should be based on an assessment by the Fund of a member's underlying payment capacity and its prospects of regaining market access. Cases are expected to fall broadly into four categories:

- $\quad$ Those where policy adjustment and official financing should allow the member to regain full market access reasonably quickly. This is essentially the traditional

\footnotetext{
${ }^{44}$ See the Annex for a full statement of the relevant paragraphs. I am grateful to Mark Allen of the IMF for allowing me to draw on material he has provided.
} 
catalytic approach. The framework specifies that extraordinary access to Fund resources should be exceptional, and that high levels of access to Fund resources require substantial justification, both in terms of its likely effectiveness and of the risks of alternative approaches;

- $\quad$ Those where official financing and policy adjustment need to be combined with encouragement to creditors to reach voluntary arrangements to overcome their coordination problems;

- Those where the early restoration of full market access on terms consistent with medium-term external sustainability is judged to be unrealistic, and further action by private creditors, possibly including comprehensive debt restructuring, may be needed in the context of a Fund-supported program to provide for an adequately financed program and a viable medium-term balance of payments; and

- $\quad$ The extreme cases where the member may have to resort to a temporary payments suspension or standstill pending action by its creditors to support the restoration of viability. In such cases, the Fund would be prepared to lend into arrears to private creditors, provided the country is seeking to work cooperatively and in good faith with those creditors and is meeting other program requirements.

There are recent examples of programs in each category. The Brazilian program in March 2000 fell into the second category, and it was judged in the fall of 2000 that Turkey fell into that category too. The Argentine debt restructuring in the spring of 2001 was perhaps consistent with the third category, though full market access was not in the 
end restored. And Ecuador in 1998-99, in which the IMF did lend into arrears to private creditors, fell into the fourth category

Note that the framework does not use the words "liquidity" and "solvency" to categorize different cases. If the distinction were being used, cases 1 and 2 would be liquidity cases, and 4 would be a solvency case, with 3 not clear. The distinction is not used because, although analytically extremely helpful, it is difficult to apply to sovereign debtors. For them, the distinction is largely political, for solvency depends on the extent to which a government can or wants to reduce domestic demand in order to continue to service its debt. For instance, following the exchange rate crisis in February 2001, the Turkish government faced the choice of undertaking a massive fiscal adjustment in order to continue servicing its debt, or attempting a debt restructuring, which would probably have had to be involuntary. It chose the fiscal adjustment.

Nonetheless four serious difficulties arise in applying this framework. The first became clear following the revised Turkey program in December 2000, after a voluntary agreement on a rollover of interbank lines had been reached with Turkey's commercial bank creditors. At that point the program looked likely to succeed, and the voluntary agreement by the banks could be seen as the solution to a collective action problem. But then during the next few months the markets' confidence in the Turkish program began to weaken, and the banks began to pull out their lines. ${ }^{45}$ Given that the program was not going perfectly, it was difficult for the official sector to insist as strongly as before on the banks rolling over their lines.

The second difficulty lies in the enforcement of these voluntary agreements. In the 1980 s, the authorities in the creditor countries exerted pressure on their banks, doing

\footnotetext{
${ }^{45}$ Part of the decline in interbank lines was a result of a decline in demand by Turkish banks.
} 
so to solve the collective action problem - namely, that if the banks agreed to provide the required amount of funding, each bank individually would be better off than it would have been had it done what seemed best for it, acting alone, which was to attempt to withdraw its funds. Bank regulators have been much less enthusiastic about exerting such pressure in recent years, for they see a conflict between their regulatory role, and their pressuring the banks to maintain portfolio positions against their will. Some industrial country regulators argued that it was up to the authorities in the crisis country to persuade the banks to hold their lines. But typically the crisis country has very little leverage in this situation. It is similarly difficult for the IMF to exert any leverage if the industrial country regulators are not also doing so. The key issue is whether by exerting pressure the industrial country regulators are indeed helping all involved, including the banks, to reach a better equilibrium - and a judgment on that issue could be made case by case.

The third difficulty is in the notion of voluntary market-based restructurings of the debt. To a first approximation, a purely voluntary market-based restructuring cannot reduce the present value of a country's debts, for the country will simply be trading the debt up and down the term structure. ${ }^{46}$ Thus not much should be expected from purely voluntary debt restructurings, though changes in the profile of debt payments - for instance pushing them out into later years - could be useful if the country has a temporary liquidity problem. The country could achieve a reduction in the debt burden by reducing the seniority and thus the value of existing claims in some way. And perhaps it could achieve some reduction in the debt burden by enhancing some new claims with the aid of financing or guarantees from the official sector, where the reduction in the

\footnotetext{
${ }^{46}$ The present value of the debt could change as a result of changes in the term structure of interest.
} 
value of the debt will be approximately equal to the reduction in the present value of interest payments implied by the substitution of lower interest official debt for higher interest market debt.

The fourth, most profound, difficulty occurs in the "extreme cases where the member may have to resort to a temporary payments suspension or standstill pending action by its creditors to support the restoration of viability." The problem is that there is no accepted framework in which a country in extremis can impose a payments suspension or standstill pending agreement with its creditors to support the restoration of viabilityand that accordingly any country contemplating a standstill faces enormous uncertainties about what will happen to the economy if it does so. Those uncertainties are compounded by the absence of an accepted legal framework in which the debtor and its creditors can work to seek to restore viability.

Indeed it is striking that when governments face the decision on whether to seek to impose a standstill and/or restructure the debt in a non-voluntary way, they are generally willing to go very far to avoid a default - especially so the countries that have adopted drastic solutions in the past, such as default, deposit freezes, and exchange controls.

A standstill could be appropriate and sufficient in a pure liquidity crisis, as a way of stopping a self-justifying run. However, a standstill might be the prelude to a restructuring. There is no way of knowing until after the dust has settled. Why are countries so reluctant to go down this road, especially given the frequency with which critics of IMF rescues argue that a default would be better for the international system and the country? The reasons are: that a debt restructuring will almost certainly involve a 
restructuring of the domestic financial system, where financial institutions - including banks and pension funds - hold government bonds as important parts of their portfolios; that it is impossible to know what interruptions there will be to the payments mechanism and to trade credit; and that it is impossible to know when domestic and foreign confidence in the government's ability to meet its promises will be restored, and for how long the country will be punished by the markets for having defaulted. Rightly or wrongly, probably rightly, debtor governments see the costs of a debt default as extremely large - and much larger than the critics of IMF loans typically imply.

The desire of countries to avoid default raises difficult issues for the official sector: it would be natural for the official sector to be on the side of those who want to honor contracts, and not to force default on countries that are willing to undertake the policies needed to avoid it - provided the country has a reasonable probability of doing so successfully. But there will be occasions when the probability of finding a way out of a crisis without a debt restructuring and writedown is low, and it is then that the official sector will find that it should not provide further assistance. It is the judgment of how far to go to help a country that seeks to avoid a default, and of what probability of success to require, that lies behind the controversies over recent IMF support for Turkey, its decision to support Argentina in August 2001, and not to provide further support to that country in December 2001.

What can be done $?^{47}$ The most important suggested innovation is the creation of a legal procedure for sovereign bankruptcy, which would require finding legal mechanisms both to approve payments standstills by sovereigns, and for the restructuring

\footnotetext{
${ }^{47}$ See Eichengreen (2000).
} 
and if necessary writing down of sovereign debts. ${ }^{48} 49$ This is the SDRM or Sovereign Debt Restructuring Mechanism, which has been so forcefully supported and advanced by my successor at the IMF, and a previous Harms lecturer, Anne Krueger.

What criteria need to be considered in deciding whether to make improvement in standstill and/or bankruptcy procedures for sovereigns a high priority? The costs of resorting to such measures have to be high if the credit mechanism is to work well. If creditors believe emerging market debtors will too easily use legal provisions to restructure debts, spreads will rise and capital flows to those countries will decline. That is why policymakers from emerging market countries generally oppose proposals to make it easier for them to restructure their payments, be it through collective action clauses or the creation of a sovereign bankruptcy procedure.

Nonetheless, the absence of procedures for dealing with situations where debts have a very high probability of becoming unsustainable, distorts the behavior of the international system. Under present circumstances, when a country's debt burden is unsustainable, the international community - operating through the IMF - faces the choice of lending to it, or forcing it into a potentially extremely costly restructuring, whose outcome is unknown. The official sector is likely to go very far to help countries that are willing to take the necessary measures to avoid debt defaults, but debts will sometimes have to be written down. That could be costly for the country concerned, but not as costly as it is now.

\footnotetext{
48 National bankruptcy laws would apply to private sector debtors who cannot make payments; if debtors can pay in local currency, the stay could permit a delay in converting these payments into foreign currency.

${ }^{49}$ It is often argued that Article VIII-2b of the IMF Articles of Agreement could serve as the basis for international approval of a payments standstill imposed by a member of the Fund. However this judgment is not shared by the IMF's lawyers, who point out that VIII-2b applies to exchange controls on exchange contracts, not to payments on debt contracts.
} 
Such a change in the international system would inevitably affect the nature and direction of capital flows, and we can be sure that if legal changes are made, the creditors will seek ways of restructuring debt contracts to minimize the impact of the new framework. But we could also reasonably hope that such provisions would lead to more differentiation among countries, with flows increasing to those countries unlikely to need to use the bankruptcy mechanism, and relative spreads rising for those more likely to have to use it, thereby providing important incentives to strengthen the structure of the economy and economic policies.

So it is certainly desirable that the IMF continue its important work on this topic. But we should recognize that at best it will take many years to change the legal framework, and that it is quite possible that it will not in the end be possible to persuade the U.S. Congress on this issue. In any case, I believe the Executive Board of the IMF could make a contribution to this effort by describing in advance a set of procedures for how it will act in event it concludes that countries have an unsustainable level of debt. This would help formalize the approach that has already been developed on an ad hoc basis in response to some of the recent crises. At the very least, it would provide more clarity on the question for debtors and creditors alike, which would be a good in itself.

The G-10 deputies' proposal for collective action clauses (CACs) in bond contracts, which should make them easier to restructure, is another possibility. ${ }^{50}$ Ironically the Krueger proposal for an SDRM seems to have achieved one important

\footnotetext{
${ }^{50}$ This proposal led to an Alphonse and Gaston act in which emerging country bond issuers announced they would be willing to follow industrialized countries in including such clauses, while the industrialized countries generally explained that they had no need for them. In 2000, the United Kingdom did include such a clause in a Euro issue, in the hope that other countries would follow.
} 
result in persuading the private sector to support CACs. However, emerging market countries have resisted the suggestion, arguing it would raise spreads. ${ }^{51}$ At present some emerging market countries are considering whether to include CACs in future bond contracts - and if they do, that will achieve many of the goals of a more complete SDRM.

There has been some fear that inclusion of CACs will create moral hazard on the part of borrowers, who will be too quick to seek to restructure their debt obligations. I doubt this will happen, for the issuers have generally fought vigorously to avoid defaults. If there is a hazard in the adoption of CACs, it is that the official sector will become too quick to urge restructurings as an alternative to IMF lending. There is a balance to be struck, and most of its members believe it is important that the IMF not step back from the provision of financial resources to countries facing a liquidity crisis.

\section{The Operation of the International Capital Markets}

As the Mexican crisis developed, and as the Asian crisis intensified, it was easy to conclude that the capital markets were too powerful and too volatile, that contagion was excessive, and that they failed to discriminate appropriately among different levels of performance. And there were certainly occasions during the crisis when I felt that each of these charges was justified. It was less obvious what to do about them.

One response would have been for countries to close themselves off from the international capital markets. It is striking that despite the blandishments of events and

\footnotetext{
51 The strong opposition to the initial (1996) proposal for CACs became less persuasive when it was realized that such clauses already existed in so-called British trust-deed bonds, and that no-one had noticed. Subsequent empirical research by Eichengreen and Mody (2000) suggested that the inclusion of such clauses reduces spreads for high quality borrowers and raises them for less sound borrowers - an appealing result, though one that is the subject of ongoing research.
} 
some well-known economists, no country - including Malaysia, which removed almost all its controls within less than two years after imposing them - did that. ${ }^{52}$ Emerging market country policymakers must have thought it useful to remain within the international financial system despite the problems that had caused for them.

Is there any way of establishing that the international capital markets are inefficient? $?^{53}$ As we know from the literature on the stock market, it is difficult to prove empirically that asset prices fluctuate excessively. But let me mention a few pieces of evidence.

Larry Summers has argued that there is an inconsistency between the pricing of emerging market bonds and the frequency of defaults: specifically, that spreads are so high as to imply a substantial probability of default, but defaults have been few. ${ }^{54}$

Another striking fact has been the contagion that has been seen in the emerging markets - in the Mexican crisis, during the Asian crisis, in the Russian crisis, and perhaps in the current Brazilian crisis. However, I should add that I do not believe the current difficulties in Brazil are primarily a result of contagion from Argentina; rather they mainly reflect political uncertainties in Brazil.

There are some good reasons for contagion among related markets - for instance, the stock prices of firms in the same industry tend to move together, but its extent in the Russian crisis was surely excessive. Further, the explanation that contagion spread to the

\footnotetext{
${ }^{52}$ To be sure, several countries did impose measures seeking to control or close access to offshore markets in their currency.

${ }^{53}$ It may be even more difficult to establish excess variability if there are multiple equilibria. Presumably the test of efficiency would then have seek to establish whether the system was in a good or a bad equilibrium at any given time. There have been several crises during which I was convinced we were in a multiple equilibrium situation, in which the government's policies would be fully viable if spreads were lower - the good equilibrium - but that the policies were not viable at actual spreads - the bad equilibrium. But I do not know how to establish that was the case.

${ }^{54}$ This argument is developed at greater length in Fischer (2001b).
} 
stronger emerging markets in part because emerging market traders needed cash, which was most easily obtained in a relatively strong market, suggests a market inefficiency in which limited liquidity in the market as a whole distorts pricing relations among the different countries' bonds. ${ }^{55}$

During crises, the IMF sometimes heard suggestions that a particular course of action should be taken "for the good of the asset class". This is not a compelling basis for making a decision on an individual country, but it does support the view that treating emerging market bonds as a separate asset class distorts asset pricing among emerging market countries. Perhaps emerging market asset price determination would become more efficient if the bonds of the different emerging market countries were no longer treated as an asset class.

The data strongly suggest that the markets are doing a better job of discriminating among countries now than they did during the Asian and Russian crises. Spreads vary widely, no major anomalies in the ranking of spreads are immediately obvious, and despite current market tensions, several countries with good macroeconomic policies have spreads that appear relatively low by their historical standards, for instance Mexico, Poland, and South Africa.

Possibly we are in a period in which relative asset pricing among the bonds of the emerging market countries is becoming more efficient, and in which the countries with strong fundamentals, high transparency, and good investor relations programs are being rewarded by the markets. But we should also remember that the overall flow of resources

\footnotetext{
${ }^{55}$ Some of the explanations for contagion in the Mexican crisis also relied on the rebalancing of dedicated emerging market funds.
} 
to the developing countries is highly variable, and that we are once again in a period in which gross flows are extremely low, and net flows are almost certainly negative.

In 1997 there was much talk about there being no need for the IFIs because the private markets were doing the job of financing the developing countries. That was never true for the smaller less developed countries, but the variability of private sector flows in recent years has led many to believe that the official sector should have the responsibility for trying to offset some of the fluctuations in private flows. ${ }^{56}$

\section{Concluding Comments}

Paul Volcker remarked during the debate over the international financial architecture that the proposals for reform were more like interior decorating than architecture. The proposals discussed in this lecture indeed lack the grandeur of the vision of the global economy that the wartime generation put in place, and the issues are less important for the behavior of the international system than those that on the agenda of international monetary reform in the 1970s. But they are critical for the emerging market countries, and that is reason enough to treat them as matters of the highest priority.

Those who favor a more thoroughgoing reform of the system - including Paul Volcker - focus on the exchange rate system among the major currencies. There is no question that such fluctuations have been disruptive, and that changes in the yen-dollar rate contributed to the Asian crisis - given the peg of emerging market Asian currencies

\footnotetext{
${ }^{56}$ The argument that IMF lending creates moral hazard implies that spreads are on average too low. That point does not jump out of the data.
} 
to the U.S. dollar. But for now and the foreseeable future there is no prospect of changing the flexible exchange rate system among the major currencies.

Would emerging market countries be better off giving up their currencies and dollarizing or euro'izing? I believe that will ultimately happen, but that for a long time, most emerging market countries will continue to allow exchange rate flexibility. Had exchange rates been flexible, most of the famous crises of the last decade would either not have happened, or would not have taken the form they did. That is why the shift to flexible rates among the emerging market countries is the most important change in the international financial architecture during the past decade, which should greatly reduce the frequency of crises. But as we see in Brazil at present, the adoption of a flexible exchange rate regime does not prevent all external crises, for debt-sustainability crises will still occur.

What else could be done? All the measures we have discussed to prevent crises by strengthening individual economies - including lower debt to GDP ratios - will contribute to the better performance of those economies and the international system. So will lessons learned by the IMF from the recent crises. So too should better supervision by industrial country regulators over the financial institutions active in international markets, and more provision of information by those institutions.

The major unresolved issue is the framework for private sector involvement. Sometimes countries, like companies, need either a pause in their debt servicing (in a liquidity crisis) or a permanent reduction in the burden of debt servicing (in a solvency crisis). The international financial system will not work well unless the imposition of a 
standstill or debt reduction is extremely costly to a country, and very rare. But that cost is probably currently too high.

The introduction of collective action clauses in bond agreements will help reduce the costs of restructuring when that is necessary. But the balance between creditors and debtors could also be tilted by changing the legal framework for standstills and debt restructurings. What would happen to the international capital markets if the rules could be changed in this way? The initial reaction is to think that flows would decline, and spreads would rise. But there is another, more likely, possibility: that with more room for more orderly resolution of crises, and less risk of extreme crises, flows would soon rise and spreads would decline as the stability of emerging market economies grows.

What should we expect? Measures already in place or under way will increase the stability of the international capital markets, and as normalcy returns to the global economy, should also lead to greater flows to countries that are managing themselves well. It is desirable that work on developing a better legal framework for standstills and sovereign debt restructuring gets under way, but will take time to complete and longer to agree. If the apparent improvements in the ability of the international capital markets to discriminate among countries continues, thereby helping provide incentives for good behavior, the system could be operating far better, with fewer crises, even before a new legal framework is in place. 


\section{ANNEX}

From the Communiqué of the International Monetary and Financial Committee of the Board of Governors of the International Monetary Fund; September 24, 2000; Press Release No.00/54

\section{Private Sector Involvement}

21. The Committee endorses the report by the Managing Director on the involvement of the private sector in crisis prevention and management. It welcomes the progress on developing a framework for involving private creditors in the resolution of crises. The Committee notes that this approach strikes a balance between the clarity needed to guide market expectations and the operational flexibility, anchored in clear principles, needed to allow the most effective response in each case. The Committee notes that Fund resources are limited and that extraordinary access should be exceptional; further, neither creditors nor debtors should expect to be protected from adverse outcomes by official action.

22. The Committee agrees that the operational framework for private sector involvement must rely as much as possible on market-oriented solutions and voluntary approaches. The approach adopted by the international community should be based on the IMF's assessment of a country's underlying payment capacity and prospects of regaining market access. In some cases, the combination of catalytic official financing and policy adjustment should allow the country to regain full market access quickly. The Committee agrees that reliance on the catalytic approach at high levels of access presumes 
substantial justification, both in terms of its likely effectiveness and of the risks of alternative approaches. In other cases, emphasis should be placed on encouraging voluntary approaches, as needed, to overcome creditor coordination problems. In yet other cases, the early restoration of full market access on terms consistent with mediumterm external sustainability may be judged to be unrealistic, and a broader spectrum of actions by private creditors, including comprehensive debt restructuring, may be warranted to provide for an adequately financed program and a viable medium-term payments profile. This includes the possibility that, in certain extreme cases, a temporary payments suspension or standstill may be unavoidable. The Fund should continue to be prepared to provide financial support to a member's adjustment program despite arrears to private creditors, provided the country is seeking to work cooperatively and in good faith with its private creditors and is meeting other program requirements. The Committee urges progress in the application of the framework agreed in April 2000, and in further work to refine the analytical basis for the required judgments, and it looks forward to a progress report by its next meeting. 


\section{References}

Ariyoshi, A., K. Habermeier, B. Laurens, I. Otker-Robe, J. Canales-Kriljenko, and A. Kirilenko. (2000). Capital Controls: Country Experiences with their Use and Liberalization. IMF Occasional Paper 190: May.

Berg, A., E. Borensztein and C. Pattillo (forthcoming). Assessing Early Warning Systems: How Have They Worked in Practice? IMF working paper.

Bekaert, G., C. R. Harvey and C. Lundblad (2002). Does Financial Liberalization Spur Growth? Presented at the World Bank conference, Financial Globalization: A Blessing or a Curse? May: 30-31.

(http://www.worldbank.org/research/conferences/financial_globalization.htm)

Bhagwati, J. (1998). The Capital Myth. Foreign Affairs (May/June): 7-12.

Chari, A. and P. B. Henry (2002). Capital Account Liberalization: Allocative Efficiency or Animal Spirits. Presented at the World Bank conference, Financial Globalization: A Blessing or a Curse. May 30-31.

(http://www.worldbank.org/research/conferences/financial_globalization.htm)

Cushman, D. O., and T. Zha (1997). Identifying Monetary Policy in a Small Open Economy under Flexible Exchange Rates. Journal of Monetary Economics (39): 433448. 
Dobson,W., and G. C. Hufbauer (with the assistance of H. K. Choo) (2001). World Capital Markets: A Challenge to the G-10, Washington, D.C.: Institute for International Economics.

De Gregorio. J., S. Edwards and R. Valdés (2000). Controls on Capital Inflows: Do they Work? Journal of Development Economics (63): 59-83.

Edwards, S. (1999). How Effective are Capital Controls?. National Bureau of Economic Research WorkingPapers (7413). Cambridge: National Bureau of Economic Research, Inc.

Eichengreen, B., D. Mathieson, B. Chadha, A. Jansen, L. Kodres, and S. Sharma. (1998). Hedge Funds and Financial Market Dynamics, IMF Occasional Paper (166): May.

Eichengreen, B. and A. Mody (2000). Would Collective Action Clauses Raise Borrowing Costs? National Bureau of Economic Research Working Paper (7458). Cambridge: National Bureau of Economic Research, Inc.

Eichengreen, B. (2000). Can the Moral Hazard Caused by IMF Bailouts be Reduced? Geneva: International Center for Monetary and Banking Studies and London: Centre for Economic Policy Research. 
Eichengreen, B., Mussa, M., Dell'Ariccia, G., Detragiache, E., Milesi-Ferretti, G., and Tweedie, A. (1999). Liberalizing Capital Movements: Some Analytical Issues. Economic Issues (17): March

Favero, C.A. and F. Giavazzi (2002). Why are Brazil's Interest Rates so High? Mimeo. Innocenzo Gasparini Institute for Economic Research. Bocconi University. July.

Fischer, S. (1998). Capital Account Liberalization and the Role of the IMF. Princeton Essays in International Finance (207): 1-10.

Fischer, S. (2001a). Exchange Rate Regimes: Is the Bipolar View Correct? Journal of Economic Perspectives (15). (2). Spring: 3-24.

Fischer, S. (2001b). The International Financial System: Crises and Reform (under revision). The Robbins Lectures. October 29. (http://www.iie.com/fischer/sl.html).

Gallindo, A., A. Miicco and G. Ordoñez (2002). Financial Liberalization and Growth: Empirical Evidence. Presented at the World Bank Conference, Financial Globalization: A Blessing or a Curse. May 30-31.

(http://www.worldbank.org/research/conferences/financial_globalization.htm)

Goldstein, M., G. L. Kaminsky and C. M. Reinhart (2000). Assessing Financial Vulnerability. Washington, D.C.: Institute of International Economics. 
Goldstein, M. (2002). Managed Floating Plus. Policy Analyses in International Economics 66. Washington, D.C.: Institute for International Economics (March).

Gourinchas, P., O. Jeanne (2002). On the benefits of Capital Account Liberalization for Emerging Economies. Presented at the World Bank conference, Financial Globalization: A Blessing or a Curse. May 30-31.

(http://www.worldbank.org/research/conferences/financial_globalization.htm)

IMF (2000). Debt and Reserve-Related Indicators of External Vulnerability. (http://www.imf.org/external/np/pdr/debtres/): March 23.

Ishii, S., I. Otker-Robe, and L. Cui, (2001). Measures to Limit the Offshore Uses of Currencies - Pros and Cons. IMF Working Paper WP/01/43:April.

Kaplan, E. and D. Rodrik. (2001). Did the Malaysian Capital Controls Work? Mimeo. (http://ksghome.harvard.edu/ .drodrik.academic.ksg/Malaysia\%20controls.PDF)

Reinhart, C. M. and I. Tokatlidis (2002). Before and After Financial Liberalization. Presented at the World Bank conference. Financial Globalization: A Blessing or a Curse, May 30-31. (http://www.worldbank.org/research/conferences/financial_globalization.htm) 
Williamson, J. (1990). What Washington Means by Policy Reform? In J. Williamson (ed.). Latin American Adjustment: How Much Has Happened? Washington, D.C.: Institute for International Economics.

Williamson, J. (2000). Exchange Rate Regimes for Emerging Markets: Reviving the Intermediate Option. Policy Analyses in International Economics 60. Washington, D.C.: Institute for International Economics. September 